\title{
Two Parasites of the Common Cockle Cardium edule; a Rhabdocoele Paravortex cardii Hallez and a Copepod Paranthessius rostratus (Canu).
}

By

D. Atkins, B.Sc.

\section{CONTENTS,}

Paravortex cardii Hallez .

Distribution in the Plymouth Area . . . . . . . . . 672

Estuaries of the Hamoaze . . . . . . . . . . 672

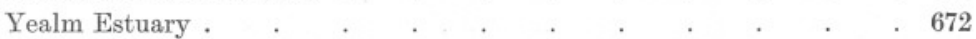

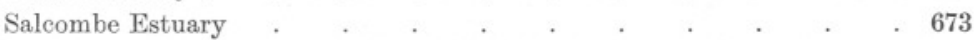

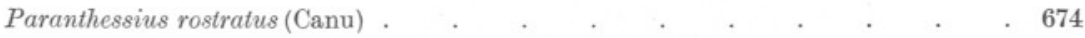

Literature . . . . . . . . . . . . . . . . . . . . 674

In view of the serious mortality reported among Cardium edule in the summer of 1933 (Orton) the following account of British parasites of this species may be of interest.

\section{Paravortex cardi Hallez.}

Apparently healthy cockles in the Plymouth area are very generally infected with a viviparous Rhabdocœle, Paravortex cardii Hallez (Hallez, 1909). In a passing reference to this parasite in a recent paper (Atkins, 1933 , p. 250) I incorrectly referred to it as Graffilla gemellipara Linton, a species known as a commensal of Modiolus demissus at Woods Hole, America (Linton, 1910).* While my paper was still in the press, but too late for correction, I chanced upon Hallez's paper on Paravortex cardii, a species of Rhabdocœle parasitic in Cardium edule from Le Portel, Boulogne-sur-Mer. Examination of the parasite of cockles from the Plymouth area showed it to be this species, and not Paravortex $(=$ Graffilla $)$ gemellipara (Linton).

The characteristics of $P$. cardii as given by Hallez (1909, pp. 430-1) are as follows: "Vorticide pourvu de deux ovaires, de deux glandes lécithogènes réticulées et anastomosées et de deux testicules globuleux; dépourvu

* Leigh-Sharpe (1933) in a note on the occurrence of a Turbellarian in a Cardium edule from Millbrook, Plymouth, also appears to have wrongly identified it as Graffilla gemellipara. The animal he figures has the appearance of being somewhat compressed. 
de bourse séminale. Orifice génital ventral situé près du pharynx en arrière, à l'extrémité du premier quart du corps. Organe copulateur mâle musculeux, dépourvu de pièces chitineuses et portant deux lobes papillifères. Pharynx doliiforme. Bouche ventrale vers l'extrémité antérieure du corps. Corps cylindrique, à extrémité antérieure plus amincie que le reste du corps, uniformément cilié, blanc légèrement jaunâtre, transparent, dépourvu de rhabdites, très contractile, ordinairement courbé en arc et tournant sur place en décrivant un cercle. Deux yeux noirs réniformes au niveau du pharynx. Longueur maxima, $1 \mathrm{~mm}$; largeur, 0.3 à $0.4 \mathrm{~mm}$. Vivipare. Nombreuses coques molles (jusqu'à 40) renfermant chacune un à quatre embryons et disséminées dans le tissu conjonctif. Les coques vides et recroquevillées restent dans le corps de la mère. Vit dans l'estomac du Cardium edule."

The reproductive organs, so far as can be seen in the living animal, are on the plan described and figured by Hallez (1909, Pl. XXVII, Fig. 20). The atrium was rarely distinguished satisfactorily. The general presence of sperm in the female atrium and oviducts and in the vesicula seminalis renders these parts of the generative apparatus clearly visible; when empty, however, the female atrium and oviducts are distinguishable with difficulty.

Ball in 1916 (p. 455) added to Linton's description of the Rhabdocœle commensal with Modiolus demissus, and (p. 459) referred it to the genus Paravortex. He (pp. 459-60) sums up the likenesses and differences of the two species as follows: "Linton's species and P. cardii are closely similar both in structure and habits. Both have essentially the same colour and the same shape of body. Both have similar digestive, sensory and glandular organs; both give birth to living young which develop in capsules within the mother's body ; both show the same peculiar movements when taken from their host and placed in sea-water.

"The two species differ, however, in that the American form attains twice the size of $P$. cardii; the genital pore is situated farther posteriorly and the ovaries are longer in the latter ;* an atrial canal in $P$. cardii leads from the dorsal part of the atrium backward to the antrum femininum, while in the American species there is no distinct canal but rather the antrum femininum extends backward from the middle of the posterior atrial surface and its opening into the latter is strongly constricted by a sphincter muscle; the openings of the shell glands in $P$. cardii are distributed along the entire ventral wall of the atrial canal and antrum femininum, while in Linton's species they all open at the anterior end of the antrum just back of the atrium; the vitello-oviducts

* This is evidently an error for "former," for the genital opening of $P$. cardii is at the end of the first quarter of the body (Hallez, 1909, p. 431); that of P. gemellipara is at the end of the first third (Ball, 1916, p. 455). 
of $P$. cardii are the longer. Linton's species lives as a commensal in the mantle cavity of the ribbed mussel, Modiolus demissus; $P$. cardii is parasitic in the stomach of Cardium edule.

"Linton's species resembles Paravortex scrobicularia rather than $P$. cardii in the form of the ovaries, i.e., they are elongated in the first two and shorter in P. cardii,"

Linton (1910) the discoverer of $P$. gemellipara stated that it was a commensal, but Patterson (1912, pp. 174-5) concluded that it lived chiefly in the kidney. Ball (1916, pp. 462-3), however, failed to find any evidence that it was other than a commensal.

Occasionally specimens of $P$. cardii from Cardium from the Plymouth area are somewhat larger than the maximum length given by Hallez, reaching at least $1.2 \mathrm{~mm}$., but measurements are difficult to make owing to the animals being very contractile, and no really satisfactory narcotic being discovered. Cocain-used by Hallez-was not obtainable ; stovain and chloretone were not successful; isotonic magnesium chloride gave fairly good results, but caused shedding of the ectoderm in a short time. The maximum length of $P$. gemellipara is given as $2 \cdot 0 \mathrm{~mm}$. (Linton, 1910, p. 372).

The greatest number of capsules containing embryos observed by Hallez in a single individual was 40 . However, a specimen, about $1 \cdot 2 \mathrm{~mm}$. long, from a Yealm Estuary Cardium, contained 47 full capsules (20 with embryos with eyes developed), while one from Neille Point had 50 to 60 full capsules, many with embryos with eyes developed. Capsules with more than 2 embryos have not been observed, though some 30 capsulecontaining specimens have been examined.

According to Hallez $(1909$, pp. 438, 446) the adult parasites are always found in the stomach of their host. The embryos escape from the body of the parent and pass into the intestine of the host, where they attain their development in some three or four days (this being the time necessary for the emptying of the gut in cockles deprived of food) and pass out by the exhalent siphon. He believes that copulation takes place normally in the intestine, but perhaps exceptionally during the free-living period. Immediately after copulation there occurs migration into the stomach of another Cardium, where the parasite completes its life history.

Hallez (1909, pp. 438-443) notes that exceptionally the formation of capsules may begin while the Rhabdocœle is in the intestine of the host. While the intestines of few Cardium were examined at Plymouth, it was found that of 14 Paravortex, the largest of which was about $0.9 \mathrm{~mm}$. long, taken from this position from 5 hosts, 7 contained 1 to 10 capsules.

The quantity of sperm in the female atrium and oviducts of young specimens is frequently much less than in large ones with many capsules: it would seem, therefore, that copulation occurs more than once, unless 
self-fertilisation takes place as Hallez supposed possible (1909, p. 444). It is of special interest that a Paravortex from a Neille Point cockle was crowded with numerous capsules the contents of which were degenerating. It seems probable that this was due to the ova being unfertilised; the only sperm visible was a minute quantity of immobile sperm in the vesicula seminalis.

\section{Distribution in the Plymouth Area.}

Estuaries of the Hamoaze. Infected cockles have been obtained from several localities.

(a) Millbrook. Of those procured on October 12th, 1933, the stomachs of the ten examined were all infected with Paravortex; the intestines were not examined. Single individuals were found respectively with : 27 parasites, all small and none carrying embryos ; 23 (7 with capsules) ; 20 (6 with capsules) ; 14 (12 with capsules) ; 10 (4 with capsules) ; 4 (one being large, with many capsules, and 3 tiny); while four individuals contained two each (all with capsules). A peculiarity of this batch was the number of small individuals.

(b) St. John's, St. John's Lake. Three small cockles, $11 \cdot 0$ to $18 \cdot 0 \mathrm{~mm}$. long, gathered on July 27th, 1933, proved to be infected. From one of these thirteen Paravortex were taken, four having 1 to 14 full capsules. Six of them, including one with 4 capsules, were taken from the intestine. The second Cardium yielded nine parasites, 4 carrying 1 to 4 full capsules. Two of them, each with a single capsule, were taken from the intestine. From the third Cardium eight Paravortex were taken, only one having capsules (8); a tiny one came from the intestine.

(c) Saint German's on the Lynher River. Twelve out of fourteen cockles $(85 \cdot 7 \%$ ) obtained on August 25th, 1933, proved to be infected. The stomachs were examined but not the intestines. Five cockles had one Paravortex each-one being also infected with the sporocysts and cercariæ (Bucephalus) of Gasterostomum ;- one had 3 ; one had 4 ; one had 5 ; two had 7 ; and one had 11.

(d) Neille Point, near the junction of the Tamar and Tavy. Four out of ten Cardium (40\%) examined on August 3rd, 1933, proved to be infected, one large Paravortex being taken from the stomach of each (the intestines were not examined). The number of full capsules present in these individuals was $22,26,50$ to 60 ; in one they were too numerous to count.

(e) Stonehouse Pool. Twelve out of thirteen cockles (ca. 92\%), examined on August 8th, 1933, were infected. The stomachs only were examined : five individuals had 1 parasite each ; one had 3 ; one had 4 ; two had 5; one had 6 ; one had 8 ; and one had 14.

Yealm Estuary. Cardium from this locality are very generally infected ; 
of five small individuals especially examined in July, 1933, four were parasitised. Details of the infection are as follows : From one cockle, 23 Paravortex were obtained, 3 only being without capsules. The number of full capsules varied from 3 to about 30 in different individuals, 13 having 10 or more. Escaped young were found in the watch glass with these adults. Seven specimens were a millimetre and more in length. From a second Cardium 17 P. cardii were taken, 11 having 2 to 16 full capsules. Five individuals were a millimetre and more in length. From a third Cardium 7 parasites were taken, 3 with 1 to 10 full capsules. Two were a millimetre and more long. From a fourth cockle 3 parasites were taken. Of two, about $1.2 \mathrm{~mm}$. long, one had 47 full capsules, the embryos of 20 having eyes already formed, and the other 31 full capsules, 17 containing embryos with eyes formed. The third specimen, about $0.9 \mathrm{~mm}$. long, had 2 capsules with young embryos.

Salcombe Estuary. Parasitised cockles have been obtained from Kingsbridge. Four out of seventeen (ca. $23 \%$ ) examined from this locality on August 11th, 1933, were infected. The number of $P$. cardii in a host was small, 3 having 2 each and the fourth a single specimen.

From Millbay, near the mouth of the Estuary, 6 cockles, gathered from the surface on September 5, 1933, had no Paravortex. One at least had the interlamellar spaces of the gills swarming with an Ancistrum type of Ciliate.

From these few examples it would seem that infection varies considerably in different localities, being heaviest in cockles from Millbrook, St. John's Lake, St. German's, Stonehouse Pool and the Yealm Estuary. From these five localities 31 out of 41 hosts had more than one parasite, and one had as many as 27. The infection is heavier than Hallez found at Le Portel, for he writes (1909, p. 437) : “Il est à noter que le nombre des Cardium qui n'hébergent qu'un seul individu est très élevé (43 à $52 \%$ ) et qu'il est relativement rare de trouver plus de quatre parasites dans le même estomac."

$P$. cardii would seem to have a wide distribution in the British Isles. Nicoll (1906, p. 154 and Pl. IV, Fig. 7) described as a Trematode sporocyst in $C$. edule at St. Andrews, Scotland, a form which is almost certainly this Rhabdocœle. Dr. M. V. Lebour, to whom I am indebted for the reference both to Linton's and to Nicoll's paper, has pointed out to me that she (1904, pp. 83-84) also described as a Trematode sporocyst in C. edule from Budle Bay, Northumberland, a form which is no doubt identical with the Rhabdocœle from South Devon and Cornwall. Lebour (1904, pp. 83,84$)$ found the parasite in about $75 \%$ of the cockles examined. Nicoll (1906, p. 154) states: "Rarely were there more than half a dozen in one cockle, and only in about $20 \%$ were they entirely absent." Hallez (1909, pp. 435, 436) found at Le Portel, Boulogne-sur-Mer that 141 out 
of $300(47 \%)$ C. edule examined during August, September, October and November were infected, the number of parasites in a host varying from one to twenty ; $43 \%$ contained one only. In December about $43 \%$ were infected; in February about $46 \%$. He therefore concludes that the winter has no influence on the percentage, which remains very much the same as during the summer and autumn. Analogous results were obtained in the spring. At Dannes-Camiers he found the percentage infected to reach $67 \%$.

\section{Paranthessius rostratus (Canu).}

Paranthessius (=Herrmannella) rostratus (see Canu, 1892, pp. 235-7, Pl. XXIV, Figs 1-13 ; Monod and Dollfus, 1932, pp. 143-6) has been obtained from the mantle cavity of Cardium from several localities in the Plymouth area. From Neille Point, near the junction of the Tamar and Tavy, the mantle chambers of ten cockles examined on August 3rd, 1933, were aswarm with the copepod. Thirteen cockles from Stonehouse Pool on August 8th, were all infected with Paranthessius, but not heavily. Fourteen Cardium obtained from near Saint German's on the Lynher River, on August 25th, all proved to be heavily infected : females carrying egg-sacs were numerous. Ten cockles examined of those obtained from Millbrook on October 12th were all infected: some of the adults carried egg-sacs.

From Kingsbridge on the Salcombe Estuary seventeen cockles, obtained on August 11th, were all rather heavily infected: many of the copepods carried egg-sacs. On September 5th six cockles from Millbay, near the mouth of the estuary, all proved to be infected: some of the copepods carried egg-sacs.

This copepod was first recorded in the British Isles from C. edule from Morecambe Bay, Lancashire, by Fraser (1932). Leigh-Sharpe (1933a, pp. 113-4) has since recorded it from the testis of Cardium from Millbrook, near Plymouth.

Paranthessius is a semi-parasite only (see Canu, 1892) and has been taken in tow-nettings from gulleys on the cockle beds in Morecambe Bay by Fraser (1932).

\section{LITERATURE.}

Atkins, D. 1933. Rhopalura granosa sp. nov., an Orthonectid Parasite of a Lamellibranch Heterancmia squamula L., with a Note on its Swimming Behaviour. Journ. Mar. Biol. Assoc., N.S., Vol. XIX, pp. 233-252.

Ball, S. C. 1916. The Development of Paravortex gemellipara (Grafflla gemellipara Linton). Journ. Morph., Vol 27, pp. 453-558. 
Bresslau, E. 1933. Turbellaria. Rhabdocœla. Kükenthal's Handbuch der Zoologie, Bd. 2, Lfg. 16, pp. 264-276.

Canu, E. 1891. Les Copépodes Marins du Boulonnais. V. Les semiparasites. Bull. Sci. France et Belgique, T. XXIII, pp. 467-487.

— 1892. Les Copépodes du Boulonnais. Travaux du Laboratoire de Zoologie Maritime de Wimereux-Ambleteuse. T. VI, Lille.

Fraser, J. H. 1932. Occurrence of the Cyclopoid, Herrmannella rostrata Canu, in Cardium edule. Nature, Vol. 130, p. 279.

Graff, L. v. 1913. Das Tierreich. Turbellaria, II Rhabocœlida. Berlin.

Hallez, P. 1908. Biologie d'un Rhabdocœle parasite du Cardium edule L. C.R. Acad. Sci., Paris, T. CXLVI, pp. 1047-1049.

1909. Biologie, Organisation, Histologie et Embryologie d'un Rhabdocœle Parasite du Cardium edule L. Paravortex cardii n.sp. Arch. Zool. Expér. et Gén., iv sér., T. IX, pp. 429-544, 1908-1909.

1909. Sur le Paravortex scrobicularice Wahl. Ibid., Notes et Revue, pp. Ixxii-lxxv.

Lebour, M. V. 1904. A Preliminary Note on a Trematode Parasite in Cardium edule. Northumberland Sea-Fish. Report, for the year 1904, pp. 82-84.

Leigh-Sharpe, W. H. 1933. Note on the Occurrence of Grafflla gemellipara Linton (Turbellaria) at Plymouth. Parasitology, Vol. XXV.

— 1933a. A second list of Parasitic Copepoda of Plymouth with a description of trhee new species. Parasitology, Vol. XXV,pp. 113-118.

Linton, E. 1910. On a New Rhabdocœle commensal with Modiolus plicatulus. Journ. Exper. Zool., Vol. IX, pp. 371-386.

Monod, T., and Dollfus, R. 1932. Les Copépodes parasites de Mollusques. Ann. Parasit. humaine et comparée. T. X, No. 2, pp. 129-204.

Nicold, W. 1906. Notes on Trematode Parasites of the Cockle (Cardium edule) and Mussel (Mytilus edulis). Ann. and Mag. Nat. Hist., ser. 7, Vol. XVII, pp. 148-155.

Orton, J. H. 1933. Summer Mortality of Cockles on some Lancashire and Cheshire Dee Beds in 1933. Nature, Vol 132, pp. 314-315.

Patterson, J. T. 1912. Early Development of Graffilla gemelliparaA supposed case of polyembryony. Biol. Bull., Woods Hole, Vol. XXII, pp. 173-204. 
Thompson, I. C. 1893. Revised Report on the Copepoda of Liverpool Bay. Trans. Liverpool Biol. Soc., Vol. VII, pp. 175-230. 1892-93.

WAHL, B. 1906. Untersuchungen über den Bau der parasitischen Turbellarien ans der Familie der Dalyelliiden (Vorticiden). I Teil. Die Genera Anoplodium, Graffilla, und Paravortex. Sitz. der Math. Naturwiss., Wien, Bd. 115, pp. 453-467. (Not seen personally.) 